原著

$$
\begin{gathered}
\text { 左十二指腸空腸窩ヘルニア嵌頓の } 1 \text { 例 } \\
\text { 一本邦例36例の検討一 }
\end{gathered}
$$

東京医科齿科大学第 2 外科学教室

$\begin{array}{lllll}\text { 岩 間 毅夫 } & \text { 具 栄 作 } \\ \text { 松 村 寿太郎 } & \text { 木 村 信 良 }\end{array}$

\title{
A CASE REPORT OF INGARGERATED LEFT PARADUODENAL HERNIA
}

-Review of 36 cases in Japan-

\section{Takeo IWAMA, Eisaku GU, Jutaro MURAMATSU and Nobuyoshi KIMURA}

2nd Department of Surgery, Tokyo Menical and Dental University

はじめに

十二指腸空腸弯曲部付近に発生する内へルニア，すな わち十二指腸空腸窝ヘルニアは，稀な疾患である。これ は腹膜後へルニアの過半数を占めるが ${ }^{23326)}$ ，本邦では， 1902年の新谷4) 例は36例である. われわれる最近, 左側十二指腸空腸窝 ヘルニアの嵌頓で小腸の広範切除を必要とした 1 例を経 験した。これを本邦症例 36 例に加えて検討し，臨床上の 特徴などについて報告する。

应例. 43歳, 男,

主訴 : 腹痛,

家族歷：特記すべきすのなし，

既往歷：25歳, 肺結核. 42歳, 腹部激痛発作が出現乙 たが保存的処置で軽快した。

現病歴：入院10日前に心窩部痛が出現したがすくく軽 快した. 昭和 50 年 4 月 26 日夕食後 30 分程して急に上腹部 に強い痛みが出現し食物を呕吐した．4月27日近医に入 院した. 疝痛が頻回に綝返されたが朝排便を見た. 午後 3 時血便を見，夕刻には，収縮期血圧が $90 \mathrm{~mm} H \mathrm{Hg}$ 亿低下乙 た. 腹部膨満, 疝痛が特続するため, 当科に入院した.

現症 : 黄病なく眼䀫結膜資血性, 顔貌苦悶状, 体温 $36.5^{\circ} \mathrm{C}$, 脈拍 $130 / \mathrm{min}$ 血圧 $60 \mathrm{~mm} H \mathrm{Hg}$ 以下とショック状態で あつた．肺肝境界第 5 助骨, 腹部はやや膨隆し, 腸雑音 微弱, 圧痛は上腹部に強く見られた。筋性防禦は明らか ではなかつた。直腸指診では括約筋の緊張は弱く，粘夜
に混じて薄い血液が指に付着した，尿に異常なく、イン ジカン反応陰性, 血液では, 赤血球数 441 万, 白血球数 12,000であつた. 水分電解質の補正と輸血を行い,ショ ック状態からの回腹と, 利尿を見て絞扼性イレウスとし て発症後約41時間で手術を行つた。

手術所見：開腹すると血性腹水が 中等量眝留してい た. 遊離腹䟡内に拡張した暗黑赤色の小腸系䁎を認め た.これをたどると，左側の結腸間膜下にはいり込んで いた．下行結腸間膜下には，小児頭大に一塊となつた小 腸系蹄を透見できた。また $\mathrm{S}$ 状結腸は索状の疮着で， 一 ルニフ門に引き寄せられていた。血管を損傷せ様に注 意しながら，下行結腸間膜背面に一塊となつている小腸 を引き出して調べると,これは左側の十二指空腸䈪に嵌 入したるのと判明した (図 1). 内容は全空腸拉よび大部 分の回腸であり，しかる一旦裹内に入つた小腸系蝏の一 部が再び遊離腹胳内に出て, 反时計針方向にほ注 $270^{\circ}$ 捻 れて絞扼されたものであつた. 回腸末端から $120 \mathrm{~cm}$ は襄

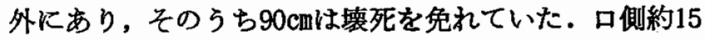
cmの空腸と肛門側約 $90 \mathrm{~cm}$ 回腸を残し $235 \mathrm{~cm}$ 小腸切除 を必要とした（図2）.

術後释過 : 術後 2 週間で吻合部からと思われる出血が 見られ，長期間多量に胃液が吸引されたが, 術直後から 経中心静脈による高カロリー輸液を行い，とくに下痢を 来すことなく経口摄取可能となつた。なお胃に対する 手術操作は行つて招らず，術後胃液検查では MAO は 
図 1 左十二指腸空腸窩ヘルニア整復後

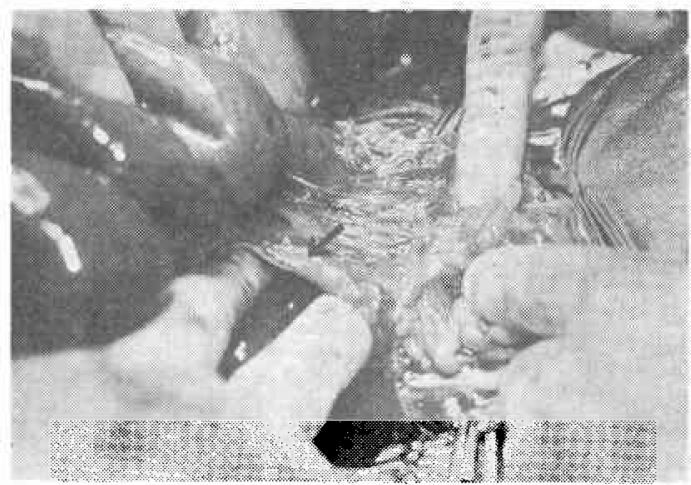

壊死小腸の嵌入していた左側十二指腸空腸窩を示 す. 術者の指を㨂入している部

図2手術所見略図

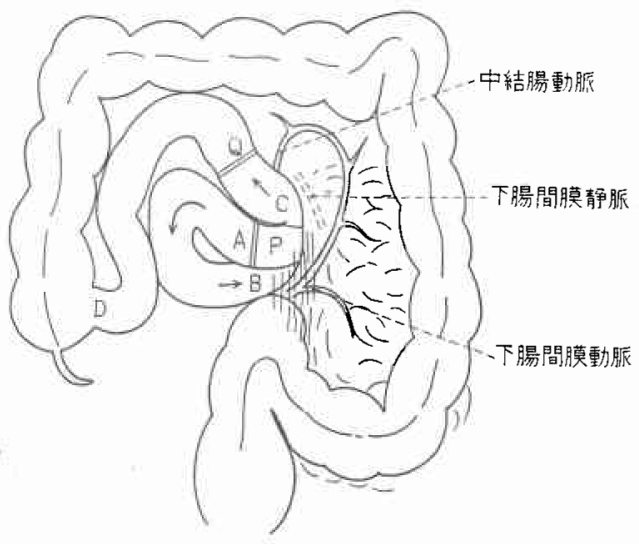

$\mathrm{A} \mathrm{B} \doteqdot 1 \mathrm{~m} \quad \mathrm{CD} \doteqdot 120 \mathrm{~cm} \quad \mathrm{QD} \doteqdot 90 \mathrm{~cm} \quad \mathrm{P}, \mathrm{Q}$, 切離吻合部 $\mathrm{A}: \mathrm{B}$, 約 $270^{\circ}$ 捻転

$\mathrm{S}$ 状結腸とへルニア入口部付近に癒着が見られた。

$19 \mathrm{mEq} / \mathrm{h}$ であつた。また空腹時血清ガストリン值は45 $\mathrm{pg} / \mathrm{ml}$ と低値を示した。

\section{考察}

Treitz (1857) ${ }^{37)}$ が十二指腸空腸弯曲部の窩について の構造を研究し，十二指腸空腸窩へルニアの成因を説 明して以来, 本症は一疾患として確立した。 その後 Moynihan ${ }^{22)}$ は十二指腸空腸弯曲部には 9 つの窩が発生 し得ることを指摘した. しかしこれらの窩と, ヘルニア との直接的関係は明かでなく，十二指腸空腸窩ヘルニア は現在では左と右とに分類されている.すなわち，下腸 膜間静脈と下晹間膜動脈で囲まれるいわゆる Treitzの
図 3 十二指腸空腸窩ヘルニア模型図

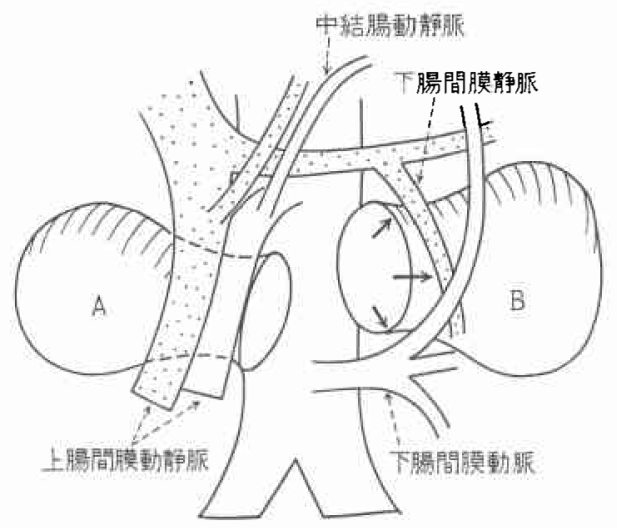

$\mathrm{A}$ ：右十二指腸空腸窝へル $=ア$

$\mathrm{B}$ ：左十二指腸空腸简へルニア

矢印：Treitz の血管弓

Gray and Skandalakis : Embryology for Surgeons. Saunders, $1972 よ り$

血管弓内に入口が存在し, 震は左側の 結腸間膜下に 向 う, 左十二指腸空腸窩へルニアと, 上腸間膜動脈が裹の 前面を走り，囊は上行結腸間膜の後方に向う右十二指腸 架晹窩ヘルニアとである (図 3).Treitz ${ }^{37}$ やMoynihan ${ }^{22)}$ は本症の成因について, 腹膜葉の後腹膜への癒合不全に よつてできた䈑が，小腸の自由な運動珄と，後腹膜の容 易な伸展性のために，徐々に拡大されて成立するとし た. Andrews ${ }^{2)}$ はこれに対し（1）腹腔内王はどこで も同一であるはず,（2）腹挖には他に多くの窩などが 存在する。（3）多くの場合へルニア内容は全小腸また は大部分の小腸である。（4）新生児にも見られる。

（5）大網はへルニア内容にならない。などを挙げ，成 因は先天的な腸間膜の発育異常であるとした。ささに， Longacre $^{16)}$ や Zimmerman ${ }^{42)}$ らは腸回転に付随する異 常であるとし，それらを図説しているが，それによると 右十二指腸空腸窩ヘルニアは事実に反し整復不可能で, 左十二指腸空腸窩へルニアは一度腹膜が裂けねばなら ず, 説明にかなりの無理がある. Callander ${ }^{6\rangle}$ らは, 下 行結腸が後腹膜に癒合する前に小腸が Treitz の血管弓 に嵌入するのであろらとしており，この説明は理解し易 い.ささてこで十二指腸空腸窝へルニアに関する本邦報 告例を見ると，1902年の大阪府医学校病院の新谷4) る40歳女の報告例が最初で, 表 1 に示した 36例であつ た. 発症年齢 : 生後 3 日の新生児 ${ }^{34)}$ から75歳 ${ }^{35)}$ にわたつ て発症している. 20歳代に最子多い(図4). 
表 1 十二指腸空腸窩ヘルニア本邦報告例

\begin{tabular}{|c|c|c|c|c|c|c|c|c|}
\hline 報告者 i & & & 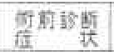 & 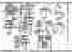 & 䉼式题 & 内容 & , & 年 \\
\hline 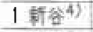 & 40 & & 8性似 $7 \mathrm{~L}$ & $4 B$ & 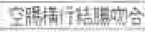 & 高基 & FE & 1902 \\
\hline 2 高安 ${ }^{111}$ & & 男 & "I & 13日 & 整葆 周粠 & 4. 4 月 $10 \mathrm{~cm}$ & 治 & 1903 \\
\hline 3 洪酯 51 & 7) 旗 & $\because 1$ & 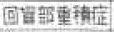 & $14 \mathrm{~B}$ & 南袺 & 空腸 & Et & 1905 \\
\hline 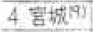 & 17 & $*$ & 䐬清呕吐 & 20 月 & Sulting & 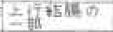 & 治 & 1924 \\
\hline 5 历州 & 65 & $p$ & 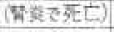 & $<$ & 剖検 & 全小腸 & $/$ & 1927 \\
\hline (c)武蕂का & 24 & $A$ & 高位化员 & 1加月 & 整慢 & 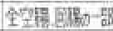 & 诒 & 1932 \\
\hline 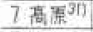 & 31 & * & 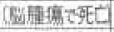 & $>$ & 新梅 & 全小墁 & $\overline{7}$ & 1933 \\
\hline (3) 平野9? & 20 & a & 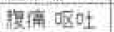 & $3 日$ & 手裙せす゚，死七 & MN & 要 & 1935 \\
\hline 9 服部时 & 41 & A & 胆福 & 119月面 & 整, 䭪 & 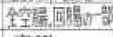 & 植 & 1936 \\
\hline (10 $\# \pi^{(3)}$ & 14 & " & 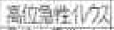 & $2 \mathrm{~B}$ & 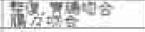 & 空樶 & $" 1$ & 1937 \\
\hline 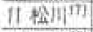 & 25 & 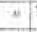 & 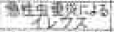 & 12 勘间 & 整得 & S犾结嗄 & 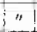 & 1937 \\
\hline 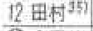 & 12 & $* 1$ & 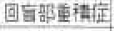 & $30 \pi$ & 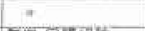 & 小腸の一期 & 1 & 1939 \\
\hline (3) 山田 38) & 46 & $"$ & 1レフス & $25 \%$ & SFe & Thong & $"$ & 1940 \\
\hline 14 费山 $^{3)}$ & 20 & & 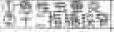 & 2 朋月 & 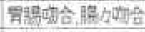 & 空螎の一部 & " & 1940 \\
\hline 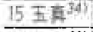 & 22 & 雾 & 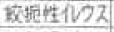 & 30時间 & 整椱 芴稍 & Q 腹 $15 \mathrm{~cm}$ & ": & 1940 \\
\hline 16 呤木 $^{307}$ & 66 & 女 & (幽聞露) & 情然 & 4 & 势: & " & 1952 \\
\hline 711 & 66 & 男 & 高估化フス & 43 & 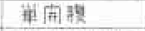 & 大部分D小惕 & 花 & 1952 \\
\hline 18 伊沼 ${ }^{123}$ & 26 &. & $1\llcorner\geqslant 7$ & $10 \mathrm{E}$ & 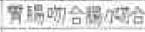 & & $3 a$ & 1954 \\
\hline 19 大谷 $^{27}$ & & $"$ & & 24 晴国 & 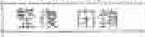 & W & - & 1956 \\
\hline (5) & & $"$ & 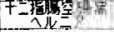 & $x \rightarrow$ 且 & $=\quad$ r & 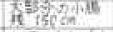 & $=$ & 1959 \\
\hline 21 吉武 ${ }^{401}$ & 26 & 女 & 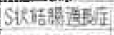 & $2 \pm H$ & $=\quad \quad$ & 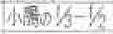 & - & 1960 \\
\hline 22 寺周 36 & 70 & $"$ & 上榎鄂巽腫 & $<$ & > & $\infty$ & in & 1963 \\
\hline $23 n$ & & 男 & 㩊性湢后 & $>$ & 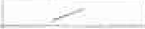 & 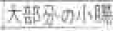 & fit & 1963 \\
\hline 24 大柣 & 39 & $"$ & (oping & 教力月 & 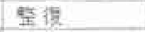 & $6 \mathrm{~cm}$ os $1 \mathrm{l} / \mathrm{s}$ & 诺 & 1964 \\
\hline 25 东息 & 59 & $"$ & (霄穿子) & $3 x=0$ & & 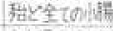 & 1 & 1965 \\
\hline (26)村同 23 & 14 & " & 急性虫重赑 & $>$ & 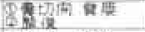 & 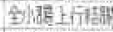 & 活 & 1966 \\
\hline 27 佳藤 299 & 1 1 33 & $1 "$ & 呕吐 & 50 胿间 & 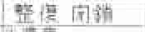 & 小膘罗位及3 & $=$ & 1967 \\
\hline (1) 1 & 15 & "I & 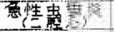 & $>$ & Af & & $=$ & 1968 \\
\hline (29) 斉藤部 & & $"$ ! & 上腹部淢 & $>$ & 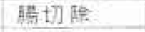 & Ret & FE & 1968 \\
\hline 30 吉野3) & 21 & & 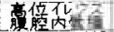 & r & 密使用祖 & is 10 & ti & 1969 \\
\hline (31) 森 $2 i 1$ & 47 & & 高位珄ウス & $>$ & 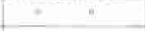 & 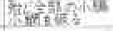 & ; & 1969 \\
\hline 32 林 ${ }^{109}$ & 24 & "i & 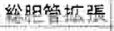 & 偶然 & 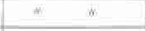 & 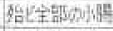 & 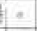 & 1970 \\
\hline $33 山+x^{2}+11$ & 2467 & & 呕 吐 & $>$ & 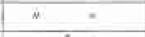 & 全郚め4晿 & 4 & 1970 \\
\hline 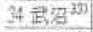 & $3 \mathrm{E}$ & & 呕吐 呕 开 & $7 日$ & $=$ & whing $30 \mathrm{~cm}$ & * & 1973 \\
\hline 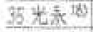 & 75 & $\frac{1}{k}$ & 蓄位体 & $>$ & 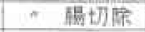 & 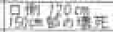 & & 1973 \\
\hline $3679^{155}$ & 19 & 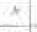 & 内人ル二P & $>$ & $\pi$ & & I & 1975 \\
\hline 3葛者 & & 恶 & 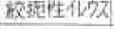 & 41時间] & Fis & The & 治 & 1975 \\
\hline
\end{tabular}

○印は右十二指腸空腸窝ヘルニア

図 4 十二指腸空腸简へルニアの年令分布

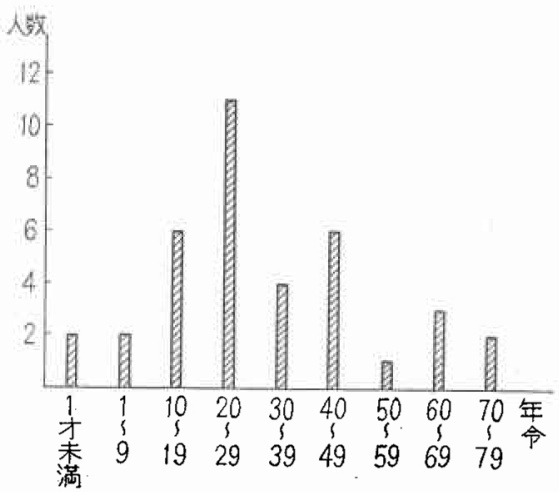

性別：男26人女 9 人，不明 1 人で男に多い. Andrews ${ }^{2)}$ によると発症は30歳から50歳までに最子多く，男女比は 44：14で男に多い，〈左右の別>左十二指腸空腸窩へル
ニアは30例右十二指腸空腸窩ヘルニアは 7 例で左側に多 w.

症状：しばしば無症状に経過し剖検や，他の疾患に対 する手術時に発見されることがある.症例 $5 ， 7 ， 16$, 25，32の 5 例がそれに当り，いずれも殆ど全ての小腸が 霬内にあつた。症状として現れるのは腹痛と呕吐であ る. 多くは急速に腸閉塞症状を現すが，腸通過障害の症 状が数週から数カ月にわたつて徐々に増大するすのや， 上腹部の不快感や呕気が長い期間続くものなどがある.

発症から手術までの時間：最短11時間》で，長いもの は数力月に执よふ(4)14) 20)24). 表 2 に示す如く, 発症 3 日 以内に手術を施行したものと，10日以上してから手術が 行われたものとに大別できる.

術前診断：（表 3）多くは腸閉塞症として手術が行わ れている.最初に受診した施設で急性虫垂炎の疑で手術 が行われた症例も ${ }^{11) 14) 26) 28)} 4$ 例ある. 術前に内へルニア と診断されたものは 3 例20)24) 36)であるが，2 例は腹部鈍

表 2 発症から手術までの時間

\begin{tabular}{|c|c|}
\hline 発聇加手術までの時間 & 薄例数 \\
\hline 24 日 時間以内 & 3 \\
\hline 2 日 & 5 \\
\hline 3日 & 2 \\
\hline 4 日 & 2 \\
\hline 5 日 & 0 \\
\hline 5 日以後10日まで & 2 \\
\hline 10日匀上 & 7 \\
\hline 合 & 21 \\
\hline
\end{tabular}

表 3 術前診断

\begin{tabular}{|c|c|}
\hline 粰 前祅 & 应到籹 \\
\hline 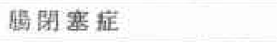 & 14 \\
\hline 急性腹症(腹痛呕吐) & 8 \\
\hline 急性虫垂炎 & 4 \\
\hline 内へル & 3 \\
\hline 回盲部重皘症 & 1 \\
\hline $\mathrm{S}$ 状結腸過長症 & 1 \\
\hline 上腹部䀼腫 & 1 \\
\hline 偶然（剖検，手術） & 5 \\
\hline 合 & 37 \\
\hline
\end{tabular}


痛が数カ月続いた症例で, 消化管造影に上り発見されて いる. Exner ") によると, 本症のX線像の特徵は，（1） あたか子袋の中に入つたように小腸が一塊となつてい る。（2）触診によつてもまたは体位の变換によつても この塊は变位しない（3）立位でも骨盤内に小腸系蹄 がない。しかし小腸の一部しか裏内に入つていない場合 は栾外の小腸は骨盤内に有ることもある．（4）襄内の 小腸は動きが悪く,バリウム通過が達れるため, 小腸の 長い範囲を一度に見ることができる、水平面を形成する こともある。（5）バリウムが襄外に出ると小腸の径が 急に変化するのが分る、などである、術前に消化管造影 の時間的余裕がある場合はこれらの所見は診断上有力で あるが，急性イレウス症状を呈する場合はこれも行い難 く，術前診断は困難である，

ヘルニア内容: 内容の明かな33例についてみると, 小 腸のみ29例, 小腸とそれに続く結腸 2 例, そして結腸の み 2 例であつた。 大網を内容とするものは 1 例るみられ ていない。

治療：治療はヘルニアを整復し，ヘルニア門を閉鎖 し，腸管壊死があればその腸管を切除する．単なる胃腸 吻合，腸々吻合などは後に障害を残すことになり避ける べきであり，最近は全く行われていない、へルニア入口 部辺縁には重要な血管が走行している.Treitz の血管户 を切離しても下行結腸の壊死を秃こさない場合もある $か^{133}$ ，整復の際には注意して扱うことが大切である.

予後：一般化予後は良い，絞扼壊死を招こすとそれだ け予後は悪くなる．最近10年間の 3 例では2 ${ }^{283)}$, 小腸切 除を行い 2 例は治癋している. 壊死部分の明らかな 6 例 （症例 8，13，17，29，35，37）を見ると，3 例（症例 8，13，37）では，へルニア襄内に入つている腸管の一 部が遊離腹腔内に出て嵌頓を扣こす，逆行性嵌頓または Wへルニアの嵌頓であつた．他の 2 例は293 35)襄外または 栾内外の壊死であり，残りの 1 例は胃切除後に沶こつた すのであつた ${ }^{17}$. すなわちへルニア内容の一部が再び避 離腹腔内に出る場合は重篤な血行障害を和こす可能性が 強くなる。

\section{左十二指腸空腸窩へルニアの岸頓で広範小腸切除を要} した 1 例を経験したので本邦報告例36例と合せて臨床的 特徴などについて検討し報告した。

\section{文 献}

1) Alexander, F.K.: The roentgen diagnosis of intraabdominal hernia, Am. J. Roent., 38:
92-101, 1937.

2) Andrews, E.: Duodenal hernia-A misnomer, Surg. Gynec. Obstet., 37: 740—750, 1923.

3）青山 勉：洀痕性腸間膜炎飞上る嵌頓性 Treitz 氏一ル $=>$ K就て, 日臨外会誌, 4：161一 $166,1940$.

4) 新谷庄吉：空腸十二指腸简嵌頓，中外医事新 報， $528: 18-19,1902$.

5）浅原慎次郎：トライッ氏後腹膜 ルルニフに就 $\tau$, 京都医事衛生誌, 141：6-8, 1905.

6) Callander, C.L.: Mechanism, Symptoms, and Treatment of hernia into the descending mesocolon. Surg. Gynec. Obstet., 60: 10521071, 1935.

7) Exner, F.B.: Roentgen diagnosis of right paraduodenal hernia. Am. J. Roentg., 28: 585-599, 1933.

8）服部大作：十二指腸空腸いル $=7$. 診と治, 23: 868-872, 1936.

9) 平野 寿：W嵌頓を起したる石側十二指腸空腸 商へルニアの 1 例. ダレンッグビート， 9 : 400-409, 1935.

10) 林 順一, 他: 総胆管抾張症に合併せる内 $\mathrm{He}-$ rnia 01 例. 中部外科学会第 5 回総会記録, 5: 32, 1970 .

11）広田耕作：十二指腸空腸窩へルニアの1例. 日 外宝函，4：528-532，1927.

12）伊沢達吉：十二指腸空腸䆚へルニアの 1 例，日 外会誌, $54: 1171,1954$.

13）井爪昌和：嵌頓トライッ氏ールニアの 1 例. 東 京医事新誌, 3062：1361-1363，1937.

14）加藤勝治, 他: 二腔心と腹腔内へルニアを合併 したきわめて稀な 1 例。最新医学, $23 ： 404-$ 409, 1968.

15）甲田安二郎：稀なールニア 3 治験例. 日臨外会 誌, $36: 237,1975$.

16) Longacre, J.J.: Mesenterico parietal hernia. Surg. Gynec. Obstet., 59: 165-176, 1934.

17）松川輝武：トライッ氏ールニア嵌頓. 日外会誌, $38: 767,1937$.

18）光永 徹：興味ある経過を示した内へルニアの 1 例。 日臨外会誌, 34:640, 1973.

19）宮城 順：十二指腸空腸弯曲部の狭棕に就て。 日外会誌, $25 ： 1222-1236,1924$ 。

20）水島嘉平：Treitz hernia を伴った胃演演穿 孔. 北海道外科雑誌, $10: 115,1965$.

21）森隆：Treitz ヘルニフの一症例. 広島医 学, $22: 192,1969$.

22) Moynihan, B.G.: Alexander ${ }^{11}$ より引用

23) 村岡正規, 他: 腹腔内 ル 28 : 767-770, 1966.

24）武藤完雄, 他 : 植物胃石に上る急性十二指腸閉 塞症並に同定の右十二指腸空腸 ルルニアに就 て. 日外会誌, 33:1181-1195, 1932. 
25）二宮景光，他：左十二指腸旁へルニア．外科診 療, 1：547-548, 1959.

26) 大梘房藏 : トライッ氏ヘルニアの 1 例, 広島医 学, $17: 34-37,1964$.

27) 大谷 彰, 他：稀有なる内へルニアの1例. 千 葉医会誌, $31: 1014,1956$.

28) 斉藤 深, 他 : 十二指腸陥凹 ルニアの一例. 日消会誌, $65: 690,1968$.

29）佐藤富良：急性腸閉塞症状を呈した幼児内一ル こアの 1 例. 日小外会誌, $4: 126,1967$.

30) 鈴木忠雄：トライッ氏へルニアの 2 例につい て. 日医大鿁, 19：102-107, 1952.

31）高原篤律: 後腹膜に於けるへルニアに就て. 実 地医家之臨床, 10：566-564，1933.

32）高安道成：嵌頓内 ヘルニアに就て. 日外会誌. 5：432-446, 1903.

33）武沼 温, 他：新生児に見られたトライッへル ニアの 1 治驗例. 児科䛦療, $36: 780,1973$.

34) 玉真俊雄，他：トライッ氏ヘルニアの1例. 大
阪医事新誌, 11, 12:1216-1222,

35) 田村一麿: 嵌頓性トライッヘルニアの 2 例. ク レッンッグビート，13：918-927, 1939.

36) 寺岡資郎, 他: Treitz's hernia の 4 例. 日臨 外会誌, $25: 145,1963$.

37) Treitz, W.: Alexander" ${ }^{1)}$ より引用

38）山田恒雄：逆行性嵌顿を起せる右側十二指腸空 晹窩ヘルニフの 1 例. 外科, 4：535-541, 1940.

39）吉野䂧三，他：左十二指腸空腸䆟ヘルニアの 1 例. 外科診療, $11: 1510-1513,1969$.

40) 吉武泰男, 他：Treitz ヘルニフの1 例. 外科. 22: $712-715,1960$.

41）山㥓望人, 他: 内へルニアの 2 症例. 日小外会 誌, $6: 73,1970$.

42) Zimmerman, I.M.: Intra-abdominal hernias due to developmental and rotational anomalies. Ann. Surg., 138: 82-91, 1953. 